\title{
Penerapan Model Pembelajaran Berbasis Pedagogi Ignasian pada Mata Kuliah Termodinamika
}

\author{
Dwi Nugraheni Rositawati \\ Program Studi Pendidikan Fisika FKIP Universitas Sanata Dharma \\ Paingan, Maguwohardjo, Depok, Sleman, Yogyakarta \\ Email : wiwikfis@gmail.com
}

\begin{abstract}
This research aims to improve academic ability and help students to be able to find the values of life that it is useful to become a whole person. This research is a research of learning that it was prepared by Ignatian Pedagogical Paradigm. The key elements in the system of Ignatian Pedagogical Paradigm are the context-experience-reflection-action-evaluation. The system is applied by lecture every meeting. Experience excavations are conducted in the laboratories that it enables students to study independently and in groups with experiment, viewing videos, working on questions, describing state diagrams, giving examples of everyday phenomena, presentations and trying to derive equations. The students reflect their experience and action to find the values of Ignatian Spirituality that it is useful for the development of student life into a whole person gained by $3 C$ (competence, conscience and compassion). The evaluation is done with observing the improvement of academic ability and the invention of life values. Implementation of Ignatian pedagogy in thermodynamics course has been able to improve academic and non academic ability of the students. The academic achievement is indicated by increasing the value of IPS and IPK. While non-academic achievement is indicated by the discovery of life values such as awareness of the need to advance, unyielding spirit, confidence, caring, discipline, systematic thinking, logical, conscientious, respecting process, independent, imaginative, responsible, self-handling, caring and moving to always try to get better.
\end{abstract}

Keywords: context, experience, reflection, action, evaluation

\begin{abstract}
Abstrak: Penelitian ini bertujuan untuk meningkatkan kemampuan akademik dan membantu mahasiswa untuk dapat menemukan nilai-nilai kehidupan yang berguna untuk menjadi pribadi yang utuh. Penelitian ini merupakan penelitian pembelajaran yang disusun dengan berbasis Pedagogi Ignasian. Unsur-unsur pokok yang merupakan sistem pada Pedagogi Ignasian adalah kontekspengalaman-refleksi-aksi-evaluasi. Sistem tersebut diaplikasikan pada setiap pertemuan. Penggalian pengalaman dilakukan di laboratorium yang memungkinkan mahasiswa untuk aktif belajar secara mandiri dan kelompok yaitu dengan praktikum, melihat video, mengerjakan soal, menggambarkan diagram keadaan, memberikan contoh fenomena sehari-hari yang terkait dengan materi, presentasi dan mencoba menurunkan persamaan. Melalui refleksi antara pengalaman dan aksi, mahasiswa diajak untuk mampu menemukan nilai-nilai Spiritualitas Ignasian yang berguna untuk perkembangan hidup mahasiswa menjadi pribadi yang utuh yang diperoleh dengan mengasah $3 \mathrm{C}$ (competence, conscience dan compassion). Evaluasi dilakukan dengan mengamati peningkatan kemampuan akademik dan penemuan nilai-nilai kehidupan. Penerapan Pedagogi Ignasian pada mata kuliah Termodinamika telah dapat meningkatkan kemampuan akademik dan non akademik mahasiswa. Peningkatan prestasi akademik diindikasikan dengan peningkatan nilai IPS dan IPK. Sedangkan prestasi non akademik diindikasikan dengan diketemukannya nilai-nilai kehidupan seperti kesadaran akan kebutuhan untuk maju, semangat pantang menyerah, percaya diri, kepedulian, disiplin, berpikir sistematis, logis, teliti, menghargai proses, mandiri, imajinatif, bertanggung jawab, mengatasi diri, bekerjasama, dan tergerak untuk selalu berusaha menjadi lebih baik.
\end{abstract}

Kata kunci: konteks, pengalaman, refleksi, aksi, evaluasi 


\section{PENDAHULUAN}

Pada dekade sekarang, dengan adanya kompetisi global menyebabkan dunia dengan IPTEKnya berkembang dengan sangat pesat. Aneka tawaran bersifat menggiurkan berupa fasilitas maupun nilai-nilai hidup. Kompetisi global yang melanda masyarakat seluruh dunia pada gilirannya juga melahirkan tuntutan terhadap perguruan tinggi untuk mereformasi diri agar mampu menghasilkan manusia unggul yang dapat memimpin dirinya sendiri, kelompok dan masyarakat dalam berkompetisi mencapai kemajuan dan keberhasilan di berbagai segi kehidupan. Hal ini sesuai dengan arah pendidikan Nasional seperti yang tertuang dalam Undang-undang Republik Indonesia No. 20 Th 2003 tentang Sistem Pendidikan Nasional yaitu pentingnya peningkatan mutu serta relevansi dan efisiensi manajemen pendidikan untuk menghadapi tantangan sesuai dengan tuntutan perubahan kehidupan lokal, nasional, dan global sehingga perlu dilakukan pembaharuan pendidikan secara terencana, terarah, dan berkesinambungan (Undang-undang Republik Indonesia No. 20 Th 2003: 1) dan sesuai dengan Peraturan Pemerintah Republik Indonesia No. 19 Tahun 2005 tentang Standar Nasional Pendidikan dimana disebutkan bahwa Standar kompetensi lulusan adalah kualifikasi kemampuan lulusan yang mencakup sikap, pengetahuan, dan keterampilan (Peraturan Pemerintah Republik Indonesia No. 19 Tahun 2005:2). Pendidikan mempunyai peranan yang sangat penting dalam proses mewujudkan manusia yang unggul (berkompetensi pada bidangnya dan berkarakter).

Pembentukan karakter tersebut salah satunya dapat dibangun dengan nilai - nilai yang ditawarkan melalui Pedagogi Ignasian. Pedagogi Ignasian adalah sebuah paradigma. Model pembelajaran berbasis Pedagogi Ignasian adalah kerangka konseptual yang digunakan sebagai pedoman atau acuan dalam melakukan kegiatan pembelajaran dengan fokus pencapaian tujuan pembelajaran yang meliputi 3C (Competence, conscience, compassion). Competence adalah kemampuan kognitif, conscience adalah kemampuan afektif untuk menentukan pilihan-pilihan yang dapat dipertanggungjawabkan secara moral, sedangkan compassion adalah kemampuan psikomotorik dan kemauan untuk mengembangkan bakat dan kemampuan sepanjang hidup dan disertai dengan motivasi untuk menggunakannya demi sesama (P3MP, 2012: 46). Pembelajaran dengan berbasis Pedagogi Ignasian tidak menjadi sekedar pengumpulan segudang pengetahuan atau persiapan untuk melaksanakan sebuah profesi melainkan lebih dari itu yaitu mengembangkan pribadi manusia seutuhnya yang akan menjadi "manusia untuk dan bersama orang lain" (Men and Woman-for and with-Other).

Menurut Hayes (2006), padanan pedagogi Ignasian dengan teori belajar adalah sebagai berikut:

1) Pedagogi Ignasian memiliki kesejalanan dengan teori belajar Plato dan Aristoteles. Plato berpandangan bahwa pengetahuan sudah terdapat dalam jiwa masing-masing pelajar. Tugas pendidik adalah membangkitkan potensi pengetahuan itu dengan metode dialektika, yaitu berdebat, berdiskusi, beradu pendapat secara teratur sampai pelajar mencapai pengertian yang benar dan mendalam mengenai sesuatu, bahkan sampai menyentuh sistem nilainya sehingga menjadikannya tumbuh secara moral. Selanjutnya menurut Aristoteles, secara singkat belajar merupakan proses self discovery dari berbagai pengalaman yang berlangsung dalam diri pelajar.

2) Pedagogi Ignasian mengandung unsur-unsur dari teori belajar yang berorientasi behavioristik yaitu: (1) proses belajar termanisfestasikan dalam bentuk perubahan tingkah laku, (2) lingkungan membentuk tingkah laku, (3) pelajar akan mengingat dan menjadikan bagian dari kebiasaan bentuk-bentuk tingkah laku yang diikuti, (4) pengulangan hubungan yang bermakna antara tingkah laku dan kondisi tertentu akan meningkatkan proses belajar, (5) kesiapan dalam arti kematangan menentukan proses 
dan hasil belajar, (6) pentingnya memberikan penghargaan atas perilaku pelajar yang diharapkan akan diulanginya.

3) Pedagogi Ignasian mengandung unsur-unsur dari teori belajar yang berorientasi kognitif, yaitu: (1) struktur kognitif internal manusia yang mengalami perkembangan akibat faktor kematangan atau karena interaksinya dengan lingkungan, (2) belajar harus dibedakan menjadi belajar yang bermakna (meaningful learning) dan belajar hafalan (rote learning), (3) belajar dapat melalui proses penemuan (discovery learning).

4) Pedagogi Iganasian mengandung unsur-unsur dari teori belajar yang berorientasi humanistik, yang menekankan pentingnya kombinasi dimensi kognitif dan afektif dalam pembelajaran.

5) Pedagogi Ignasian mengandung unsur-unsur dari teori belajar yang berorientasi sosial (social learning theory), yaitu: (1) manusia belajar tidak melulu dengan cara mengamati tetapi juga dengan meniru dan memperteguh hasil pengamatannya, (2) proses belajar dapat berlangsung dengan mengamati (termasuk lewat imajinasi) tingkah laku orang lain beserta konsekwensinya, sehingga pelajar mampu menata tingkah lakunya berdasarkan pertimbangan atas berbagai konsekwensi yang bisa dibayangkan sendiri.

6) Pedagogi Ignasian mengandung unsur-unsur dari teori belajar yang berorientasi konstrukstivis yaitu: (1) pelajar mengonstruksi pengetahuannya sendiri berdasarkan interaksinya dengan lingkungannya, (2) pendidikan dan pembelajaran harus mampu menumbuhkan keberanian dalam diri peserta didik untuk mengubah cara berpikirnya atau paradigmanya.

Karena model pembelajaran berbasis Pedagogi Ignasian memiliki dukungan teori belajar yang kuat maka tidak diragukan lagi bahwa Pedagogi Ignasian dapat digunakan sebagai model pengembangan karakter bagi peserta didik. Penerapan model pembelajaran dengan pendekatan atau paradigma Pedagogi Ignasian biasanya dirumuskan melalui sebuah sistem yang memiliki unsur-unsur pokok: konteks (context) - pengalaman (experience) - refleksi (reflection) - aksi (action) - evaluasi (evaluation) (P3MP, 2012: 10). Pengolahan pengalaman berdasarkan konteks dan penekanan yang kuat pada refleksi untuk memaknai pembelajaran yang kemudian menumbuhkan aksi yang berorientasi pada orang lain, merupakan kesatuan tahapan yang diolah dalam siklus PI yang khas. Siklus ini juga akan memungkinkan pembelajar untuk berkembang menjadi lebih baik (continuous improvement) dengan adanya tahap evaluasi.

Termodinamika merupakan studi mengenai perpindahan energi yang melibatkan panas, kerja mekanik dan aspek lain dari energi serta bagaimana perpindahan tersebut dihubungkan dengan sifat sistem (Young HD, Freedman RA, 2002: 528). Mata Kuliah Termodinamika dipilih dalam model pembelajaran ini berdasarkan keprihatinan penulis berkaitan dengan konteks mahasiswa yang mengambil mata kuliah pada semester itu (Rata-rata Indeks Prestasi Kumulatif (IPK) mahasiswa kurang dari 2.5 dan mahasiswa juga terlihat tidak antusias mengikuti perkuliahan yang kemungkinan disebabkan karena pesimis/ rendah diri terlebih materi perkuliahan yang dianggap susah dimengerti). Mahasiswa belum mengenal dirinya dengan baik, merasa rendah diri dan belum mempunyai keinginan untuk berkembang/ berprestasi. Mahasiswa belum mempunyai kemandirian dan semangat belajarnya rendah. Dengan melihat konteks tersebut, mahasiswa perlu disadarkan bahwa masa depan seseorang pertama-tama ditentukan oleh adanya keinginan dan komitmen diri sendiri untuk maju dan bukan tergantung pada orang lain. Selain itu, ada faktor lain yaitu mahasiswa masih 
mempunyai cara belajar seperti ketika di SMA dan mahasiswa masih mencari pola belajar di Perguruan Tinggi. Mahasiswa diharapkan dapat menemukan cara belajar yang baik dalam mengikuti perkuliahan. Model pembelajaran berbasis Pedagogi Ignasian yang diterapkan diharapkan dapat digunakan sebagai sarana internalisasi nilai - nilai yang terkandung dalam Teori Termodinamika yang selaras dengan nilai-nilai Ignasian. Nilai - nilai yang dapat diperoleh dari pembelajaran dengan Pedagogi Ignasian tersebut antara lain berusaha mencapai keunggulan magis, peka dan peduli terhadap orang lain, berorientasi humanistik, ketulusan dan kejujuran, integritas dan tanggung jawab, rendah hati, sikap kritis, tekun, disiplin dan nilai - nilai kebaikan lainnya. Untuk mendukung pembelajaran berbasis Pedagogi Ignasian yang diharapkan akan dapat melahirkan "character building yang unggul" yang dapat digunakan sebagai bekal untuk kehidupan peserta didik yang lebih baik maka penulis mencoba untuk menerapkan Model Pembelajaran Berbasis Pedagogi Ignasian pada Mata Kuliah Termodinamika, adapun tujuan penelitian ini adalah untuk meningkatkan kemampuan akademik dan membantu mahasiswa untuk dapat menemukan nilai-nilai kehidupan yang berguna untuk menjadi pribadi yang utuh.

\section{METODE PENELITIAN}

Desain pembelajaran berbasis Pedagogi Ignasian adalah penjabaran prinsip-prinsip pembelajaran ke dalam rancangan materi dan aktivitas yang meningkatkan proses belajar individu menuju keutuhan pribadinya. Desain pembelajaran dirancang berdasarkan sistem Pedagogi Ignasian yang memiliki unsur-unsur pokok: konteks (context) - pengalaman (experience) - refleksi (reflection) - aksi (action) - evaluasi (evaluation) (P3MP, 2012: 10). Penelitian ini mengimplementasikan sistem tersebut pada setiap pertemuan perkuliahan.

Pengenalan terhadap konteks akan membantu dosen menentukan bentuk dan cara pemberian pengalaman melalui pembelajaran agar mahasiswa dapat menarik makna dari pengalaman utuhnya selama belajar, bagi hidupnya dan orang lain. Dosen sebagai fasilitator perlu mengungkap dan memahami konteks pembelajaran agar proses konstruksi keilmuan dan pemaknaan ke dalam nilai-nilai kemanusiaan mahasiswa dapat berlangsung secara efektif (P3MP, 2012: 13). Pengenalan terhadap konteks diperoleh melalui angket, wawancara/ diskusi dan hasil nilai akademik mahasiswa.

Pengalaman yang diberikan kepada mahasiswa meliputi pengalaman langsung dan pengalaman tidak langsung. Pengalaman langsung adalah pengalaman atas peristiwa yang digeluti oleh mahasiswa sendiri baik di dalam ataupun di luar kelas yang dikaitkan dengan bidang ilmu yang dipelajari. Pengalaman langsung memiliki kekuatan menstimulasi dimensi kognitif, afektif, dan psikomotorik. Penggalian pengalaman langsung dilakukan di laboratorium yang memungkinkan mahasiswa untuk aktif belajar secara mandiri dan kelompok yaitu dengan berdiskusi, praktikum, mengerjakan soal, menggambarkan diagram keadaan, presentasi dan mencoba menurunkan persamaan. Pengalaman tidak langsung adalah pengalaman yang diperoleh mahasiswa (tidak dialami sendiri) dari mendengar, membaca, dan melihat melalui berbagai media. Pengalaman tidak langsung diperoleh melalui melihat video, memberikan contoh fenomena sehari-hari yang terkait dengan materi.

Melalui refleksi antara pengalaman dan aksi, mahasiswa diajak untuk mampu menemukan nilai-nilai Spiritualitas Ignasian yang berguna untuk perkembangan hidup mahasiswa menjadi pribadi yang utuh. Dalam pembelajaran berbasis Ignasian, refleksi mempunyai peranan yang sangat penting. Dengan melakukan refleksi, mahasiswa menimbang dan memilih pengalaman-pengalamannya untuk menemukan nilai - nilai kehidupan (P3MP, 2012: 7). Refleksi dilakukan dengan mengasah 3C (competence, conscience dan compassion). 
Dalam Pedagogi Ignasian, evaluasi tidak hanya dilakukan pada aspek akademik mahasiswa saja tetapi juga pada aspek kemanusiaan. Evaluasi dilaksanakan secara periodik untuk mendorong dosen dan mahasiswa memperhatikan pertumbuhan intelektual, sikap dan tindakan-tindakan yang selaras dengan prinsip men and women for and others. Evaluasi akademik dilakukan secara tes. Sedangkan evaluasi non akademik dilakukan secara non test yang menyangkut perkembangan sikap kepribadian yang dievaluasi dengan observasi, wawancara pribadi, angket, meninjau jurnal/ buku harian mahasiswa, dan mengamati keaktifan mahasiswa.

\section{HASIL DAN PEMBAHASAN}

Pada prinsipnya proses Penerapan Model Pembelajaran berbasis Pedagogi Ignasian pada mata kuliah Termodinamika dilaksanakan dalam tiga tahap yaitu tahap persiapan, tahap pelaksanaan, dan tahap evaluasi. Masing-masing tahap dapat dijelaskan sebagai berikut:

\section{a. Tahap Persiapan}

Tahap persiapan dilakukan dengan pencarian video yang relevan dengan nilai yang akan ditemukan dalam proses perkuliahan dan terus dilakukan penambahan referensi pustaka sebagai tambahan dari acuan yang sudah ada. Video diperoleh dari koleksi pribadi. Sedangkan tambahan referensi pustaka dilakukan untuk semakin menemukan kaitan mata kuliah dengan fenomena sehari-hari yang diperoleh dari internet serta buku-buku yang relevan.

\section{b. Tahap Pelaksanaan}

Pengajar menciptakan kesempatan-kesempatan dengan maksud supaya terjadi interaksi terus menerus antara pengalaman, refleksi, dan aksi pada diri pembelajar. Melalui Pembelajaran Berbasis Pedagogi Ignasian, mahasiswa yang memiliki karakteristik pesimis dan tidak mandiri diajak untuk mampu menemukan nilai-nilai Spiritualitas Ignasian yang dapat berguna untuk perkembangan hidup mahasiswa menjadi pribadi yang utuh. Dosen berperan melayani mahasiswanya, peka terhadap bakat dan kesulitan mahasiswa, terlibat secara pribadi dan membantu pengembangan kemampuan internal setiap mahasiswa. Dosen menambahkan refleksi antara pengalaman dan aksi dalam proses pembelajaran sehingga mahasiswa mampu menemukan nilai/ makna hidup yang dapat digunakan sebagai bekal untuk melakukan tindakan. Dengan melakukan tindakan (terlebih yang magis/ unggul/ the power to do more) berdasarkan nilai maka seseorang akan dapat mengatasi/ melampaui "rasa amannya" karena dia bertindak berdasarkan nilai yang diperoleh dari pengalaman yang direfleksikan. Bila nilai tersebut terus menerus dihidupi maka akan mendarah daging dan akan menjadi energi untuk melakukan tindakan-tindakan ke arah yang lebih baik. Sehingga dari sini penerapan model Pembelajaran Berbasis Pedagogi Ignasian akan sangat membantu mahasiswa peserta mata kuliah Termodinamika yang memiliki kemampuan intelektual dan semangat yang rendah.

\section{1) Pemahaman Konteks}

Pada pertemuan awal (sebelum dimulai pemberian materi), dosen mengajak mahasiswa untuk sharing pengalaman yang sudah terjadi pada semester sebelumnya. Pengalaman yang disharingkan adalah pengalaman berhasil dan tidak berhasil serta alasan-alasannya. Kemudian mahasiswa diajak untuk dapat menemukan nilai - nilai hidup yang diperoleh dari pengalaman berhasil dan tidak berhasil tersebut. Proses ini diharapkan dapat membantu 
mahasiswa mengenal kekuatan dan kelemahan masing - masing sekaligus untuk mengetahui peluang dan tantangan yang akan dihadapi selama proses studi dan setelah lulus.

Dari sharing mahasiswa dapat diketahui bahwa mereka merasa rendah diri dan pesimis karena pada semester - semester sebelumnya satu persatu teman mereka mundur. Mereka belum bisa menerima kenyataan yang demikian sehingga mengakibatkan jadi malas mengikuti perkuliahan dan sering membolos/ tidak hadir dalam perkuliahan. Mahasiswa terlihat tidak antusias dalam mengikuti perkuliahan. Hal ini berakibat ada mata kuliah yang tidak lulus sehingga IPS dan IPKnya jelek.

Mahasiswa merasa tidak serius dalam pembelajaran pada semester sebelumnya, tidak bisa kompak dan tidak bisa kerjasama dengan teman, hanya memikirkan perasaan diri sendiri, menutup diri dan tidak dapat mengendalikan perasaan yang mengakibatkan semakin rendahnya motivasi. Pada pertemuan awal tersebut, mahasiswa sadar akan pentingnya saling tolong menolong, bekerjasama, motivasi, keterbukaan, ketekunan, tidak takut untuk mencoba, rajin, kerja keras dan ketangguhan agar dapat berbuat bagi sesama. Dari nilai - nilai yang ditemukan mahasiswa nampak bahwa mereka terbuka dan sadar akan perlunya mengenal diri, dan keinginan untuk maju yang benar-benar disadari sehingga tidak menjadi tergantung pada teman dan sadar bahwa cerah atau tidaknya masa depan seseorang pertama kali ditentukan oleh adanya keinginan dan komitmen diri sendiri untuk terus maju bukan tergantung pada orang lain. Pada perjumpaan awal dengan mahasiswa tersebut nampak bahwa mahasiswa terbantu untuk mulai menemukan konteks dirinya/ mampu menemukan diri (kekuatan dan kelemahan masing - masing), menemukan nilai - nilai hidup yang digunakan sebagai bekal untuk maju. Kemampuan menemukan diri dan nilai-nilai hidup menimbulkan semangat dan kesadaran untuk memperbaiki diri sebagai bekal dalam mengikuti proses perkuliahan Termodinamika secara lebih baik.

Setiap kali sebelum mulai aktivitas perkuliahan pada setiap pertemuan selalu dilakukan tanya jawab dan review singkat terkait dengan materi perkuliahan minggu sebelumnya. Hal ini dimaksudkan untuk mengetahui tingkat persiapan mahasiswa untuk mengikuti perkuliahan selanjutnya. Pada setiap pertemuan, mahasiswa juga diharapkan selalu membawa buku referensi terutama referensi utama yaitu buku karangan Sears, F.W, Salinger, G.L yang berjudul Thermodynamics, Kinetic Theory, and Statistical Thermodynamics dengan penerbit Reading MA: Addison-Wesley.

\section{2) Penggalian Pengalaman}

Penggalian pengalaman dilakukan dengan melakukan proses perkuliahan sesuai dengan pokok bahasan. Secara lebih rinci penggalian pengalaman dilakukan dengan melihat video, aktif dalam demonstrasi alat yaitu dengan praktikum, mengerjakan soal - soal, menggambarkan diagram keadaan, memberikan contoh fenomena sehari-hari yang terkait dengan materi, presentasi dan mencoba menurunkan persamaan serta kemudian memahami dengan mengungkapkan pengertian dari persamaan - persamaan yang dihasilkan tersebut. Seluruh proses pembelajaran dilakukan di laboratorium dan memberikan kesempatan mahasiswa untuk aktif secara mandiri dan berkelompok untuk mengetahui cara kerja dari suatu alat dan bekerjasama dalam penurunan persamaan.

Umpan balik diberikan untuk makalah yang dipresentasikan, demonstrasi alat, soal - soal yang dikerjakan, penurunan rumus yang dikerjakan secara mandiri dan berkelompok yang dipresentasikan di kelas. Umpan balik presentasi dilakukan terkait dengan pembuatan slide presentasi dan tata cara presentasi. Soal - soal yang dikerjakan diberikan umpan balik dengan cara membahas soal - soal yang sudah dikerjakan di papan tulis. Sedangkan umpan balik penurunan rumus diberikan terkait dengan sistematika dan kebenaran penulisan simbol 
besaran fisika. Untuk demonstrasi alat, umpan balik diberikan terkait dengan tata cara praktikum yang benar yang meliputi penggunaan alat, pengamatan fenomena dan pengambilan data yang benar.

\section{3) Refleksi dan Aksi}

Refleksi ini bertujuan supaya mahasiswa mampu mengasah 3C (competence, conscience dan compassion). Sehingga melalui perkuliahan ini diharapkan mahasiswa tidak hanya memperoleh kompetensi akademik (penguasaan materi perkuliahan) tetapi juga dapat mengasah ketajaman hati nuraninya dan punya hasrat bela rasa sehingga mahasiswa dapat menemukan nilai - nilai hidup dari proses dan materi perkuliahan untuk bekal melakukan tindakan selanjutnya yaitu untuk menyelesaikan studi dan terlebih lagi dapat berguna sebagai bekal ketika sudah lulus.

Refleksi merupakan bagian penting dalam pendidikan Ignasian karena menjadi penghubung antara pengalaman dan aksi (tindakan). Refleksi juga merupakan suatu proses menuju perubahan pribadi yang dapat mempengaruhi perubahan lingkup sekitarnya. Refleksi berarti mengadakan pertimbangan seksama dengan menggunakan daya ingat, pemahaman, imajinasi dan perasaan menyangkut bidang ilmu, pengalaman, ide, tujuan yang diinginkan atau reaksi spontan untuk menangkap makna dan nilai hakiki dari apa yang dipelajari (P3MP, 2012: 18).

Pendidikan nilai merupakan inti proses pembelajaran, dengan nilai sebagai bahan yang diproses dan integrasi sebagai tujuannya. Dalam pembelajaran, nilai adalah segala sesuatu yang bermakna bagi kehidupan seseorang, yang pertimbangannya didasarkan pada kualitas benar salah, baik buruk, indah tidak indah (P3MP, 2012: 19). Ada sejumlah kemampuan yang mendukung proses belajar refleksi secara umum. Kemampuan tersebut adalah pemikiran metakognitif, kesadaran yang diperluas dan hati nurani. Metakognisi adalah pemahaman dan kesadaran mengenai cara-cara pikiran bekerja. Kesadaran yang diperluas merupakan proses pemikiran yang memungkinkan merenungkan perpektif masa lalu dan antisipasi masa depan. Hati nurani dipahami sebagai kesadaran mengenai hal yang baik dan buruk. Berkat ketiga kemampuan manusiawi itulah maka orang mampu melakukan refleksi. Sistem inilah yang membuat tindakan kita semakin maju, semakin tertata, dan semakin baik. Melalui refleksi, pengalaman yang diperoleh dalam proses pembelajaran diperdalam untuk menangkap makna esensial atau arti penting dari pokok materi yang dipelajari. Melalui refleksi, pengalaman mahasiswa diharapkan menjadi bermakna sehingga mampu mendorong aksi (tindakan). Refleksi harus menjadi proses formatif yang membentuk kesadaran peserta didik mengenai sikap, kebiasaan, nilai, cara pandang dan cara berpikir mereka. Melalui refleksi, peserta didik diharapkan tumbuh menjadi pribadi yang memiliki kedalaman competence, conscience, dan compassion.

Dengan melakukan tindakan yang bersemangat magis maka seseorang akan dapat mengatasi/ melampaui "rasa amannya" karena dia bertindak berdasarkan nilai yang diperoleh dari pengalaman yang direfleksikan. Bila nilai tersebut terus menerus dihidupi maka akan mendarah daging dan akan menjadi energi untuk melakukan tindakan-tindakan ke arah yang lebih baik. Supaya tujuan tersebut tercapai maka refleksi untuk proses pembelajaran Termodinamika ini dilakukan mahasiswa setiap kali di akhir perkuliahan.

Refleksi yang dilakukan setiap kali di akhir perkuliahan tersebut dituliskan mahasiswa dalam buku harian yang dibagikan dosen pengampu mata kuliah. Setelah selesai menuliskan, buku tersebut dikumpulkan dan akan dibagi lagi pada perkuliahan berikutnya. Hal ini dilakukan supaya proses refleksi mahasiswa dapat dipantau oleh dosen. Kurang lebih 1 minggu sebelum ujian sisipan dan ujian akhir, buku tersebut dibagikan kepada mahasiswa supaya dapat dibaca dan digunakan sebagai pengingat - ingat niat - niat dan nilai - nilai yang 
sudah diperoleh selama proses. Buku tersebut dibagi pada saat sebelum ujian dengan alasan bahwa masa - masa sebelum ujian biasanya mahasiswa dalam kondisi tertekan karena beban ujian, sehingga diharapkan dengan pemberian buku harian pada masa - masa sebelum ujian dapat membantu terus memotivasi mahasiswa supaya dapat terus berjuang sampai selesai.

Untuk membantu dosen dalam mengamati aksi mahasiswa, dosen pengampu mata kuliah membuat lembar pengamatan keaktifan di kelas. Keaktifan disini adalah aktif bertanya, menjawab, maju di depan kelas untuk menjelaskan/ mengerjakan soal dan kerjasama. Masing - masing mempunyai 1 poin dimana 1 poin sama dengan nilai 5. Dan apabila mahasiswa tidak hadir maka nilai keaktifan dikurangi 5. Pengurangan nilai keaktifan yang besar berfungsi sebagai "dorongan" mahasiswa supaya dapat hadir di kelas setiap perkuliahan atau dengan kata lain pengurangan nilai ini dimaksudkan supaya mahasiswa disiplin mengikuti perkuliahan.

\section{c. Tahap Evaluasi}

Evaluasi dilakukan untuk menilai hasil proses pembelajaran yang sudah dialami mahasiswa. Jenis evaluasi yang dilakukan meliputi presentasi (10\%), tugas (15\%), catatan harian (15\%), keaktifan di kelas (10\%), ujian sisipan I (15\%), ujian sisipan II (15\%) serta UAS (20\%). Evaluasi seperti ini diharapkan dapat digunakan untuk menilai tidak hanya aspek competence tetapi juga aspek conscience dan compassion yang diperoleh mahasiswa selama proses perkuliahan.

Presentasi dinilai berdasarkan makalah yang dibuat (tertulis) dan presentasi yang dilakukan. Keaktifan di kelas dinilai berdasarkan pada pedoman Lembar Pengamatan Keaktifan di kelas yang telah diisi selama proses perkuliahan (lisan dan perbuatan). Catatan harian dinilai berdasarkan pada hasil refleksi yang ditulis mahasiswa dalam buku catatan harian dan penilaian antar teman (peer group). Sedangkan Tugas dinilai berdasarkan PR/ soalsoal yang harus dikerjakan mahasiswa dan dikumpulkan.

Evaluasi prestasi akademik mahasiswa pada proses pembelajaran mata kuliah Termodinamika dengan mengimplementasikan Pedagogi Ignasian disusun dengan mengacu pada hasil nilai mahasiswa yang diperoleh dari Sistem Informasi Akademik (SIA). Hasil nilai mata kuliah Termodinamika adalah $33.33 \%$ mahasiswa mendapat nilai A, 33.33\% mendapat nilai B dan 33.33\% mendapat nilai C. Nilai tersebut sebenarnya cukup mencengangkan dosen terutama karena pada mata kuliah prasyarat mahasiswa memperoleh nilai D dan E.

Penerapan Pedagogi Ignasian ini sungguh dapat membantu proses pembelajaran mahasiswa. Hal ini dapat dilihat dari nilai yang diperoleh pada mata kuliah termodinamika yang sudah disebutkan di atas dan dari nilai IPS dan IPK. Penerapan Pedagogi Ignasian ini ternyata juga mampu meningkatkan nilai mata kuliah lain. Hal ini diindikasikan dengan Peningkatan nilai IPS dan IPK dimana diperoleh kenaikan rata-rata IPS dari 2.10 menjadi 2.66 sedangkan kenaikan rata-rata IPK dari 2.05 menjadi 2.18. Hal tersebut sebenarnya mengindikasikan bahwa sebenarnya mahasiswa tersebut sudah menjadi lebih rajin dan disiplin dibanding semester sebelumnya (prestasi non akademik).

Beberapa kompetensi non akademik yang dapat diketemukan pada diri mahasiswa melalui perkuliahan Termodinamika ini adalah kesadaran diri akan kebutuhan untuk maju, semangat pantang menyerah, percaya diri, kepedulian, disiplin, berpikir sistematis, logis, teliti, menghargai proses, mandiri, imajinatif, bertanggung jawab, mengatasi diri, bekerjasama dan tergerak untuk selalu berusaha lebih baik. Berbagai kompetensi tersebut dapat diidentifikasi secara langsung oleh dosen saat perkuliahan dan dari buku harian mahasiswa.

Pada implementasi Pedagogi Ignasian pada mata kuliah Termodinamika ini, dosen merasakan banyak memperoleh hal baru yang selama ini tidak dirasakan ketika mengajar 
mata kuliah yang tidak dengan implementasi Pedagogi Ignasian. Dosen merasa terbantu dalam mengembangkan proses perkuliahan sehingga dengan demikian materi yang diberikan dapat semakin mendalam. Lebih dari itu, karena dari materi yang diberikan juga ditarik ke aspek conscience dan compasion maka dosen juga belajar cara refleksi dan aksi yang bisa dikatakan sebagai hal baru karena pembelajaran refleksi dan aksi diperoleh dari materi perkuliahan.

Kepuasan mengajar dirasakan ketika mengetahui bahwa hasil prestasi mahasiswa ternyata menjadi sangat baik, bahkan capaiannya dapat dikatakan cukup drastis dari semester semester sebelumnya (hal ini dapat dilihat dari IPS dan IPK mahasiswa). Kepuasan mengajar juga dirasakan karena tidak ada kuliah kosong yang disebabkan karena mahasiswa yang hadir tidak komplit. Dosen dapat merasakan bahwa mahasiswa menjadi lebih bersemangat dan nyaman selama mengikuti perkuliahan sehingga hal ini mendukung proses pembelajaran yang diharapkan.

Hal lain yang membahagiakan adalah karena dengan implementasi Pedagogi Ignasian ini, mahasiswa kelihatan terbantu dalam menemukan nilai - nilai kehidupan melalui aspek conscience dan compasion. Penemuan nilai-nilai ini ternyata mampu melahirkan penemuanpenemuan lain yang justru sangat lebih penting untuk mahasiswa yaitu kemantapan diri, kedisiplinan dan potensi diri. Penemuan nilai-nilai tersebut kiranya akan dapat digunakan dalam kehidupan selanjutnya terutama ketika sudah lulus.

\section{KESIMPULAN}

1. Penerapan Model Pembelajaran berbasis Pedagogi Ignasian pada mata kuliah Termodinamika telah dapat meningkatkan prestasi akademik mahasiswa yaitu diindikasikan dengan peningkatan nilai IPS dan IPK.

2. Penerapan Model Pembelajaran berbasis Pedagogi Ignasian pada mata kuliah Termodinamika telah dapat meningkatkan prestasi non akademik mahasiswa yaitu dengan diketemukan nilai-nilai kehidupan seperti kesadaran akan kebutuhan untuk maju, semangat pantang menyerah, percaya diri, kepedulian, disiplin, berpikir sistematis, logis, teliti, menghargai proses, mandiri, imajinatif, bertanggung jawab, mengatasi diri, bekerjasama, dan tergerak untuk selalu berusaha lebih baik.

\section{DAFTAR PUSTAKA}

Hayes, C.X. (2006). Paradoxes, parallels and pedagogy. A Case Study of Ignatian Pedagogy and of teachers' perceptions of its implementation in Australian Jesuits School. Disertasi Doktor, Australian Catholic University, Victoria.

John, ER. (1990). Contemporary College Physics. Second Edition. Addison - Wesley Publishing Company. United States of America.

Lindell Jones R. Common-Sense Thermodynamics. New York. Nova Science Publishers, Inc

Mulyatno. (1992). Panas dan Termodinamika. Edisi I. Jakarta

Peraturan Pemerintah Republik Indonesia No. 19 Tahun 2005 tentang Standar Nasional Pendidikan

Pusat Pengembangan dan Penjaminan Mutu Pembelajaran (P3MP) Universitas Sanata Dharma. (2012). Pedoman Model Pembelajaran Berbasis Pedagogi Ignasian. Yogyakarta

Sears, F.W, Salinger, G.L. (1982). Thermodynamics, Kinetic Theory, and Statistical Thermodynamics. Reading MA: Addison-Wesley 
Undang-undang Republik Indonesia No. 20 Th 2003 Tentang Sistem Pendidikan Nasional

Young HD, Freedman RA. (2002). Fisika Universitas. Edisi kesepuluh. Jakarta: Penerbit Erlangga 